\title{
Model role ředitele školy v procesu dalšího vzdělávání pedagogických pracovníků
}

\author{
Model of headteacher's role in the process of further education of teaching staff
}

\author{
Jan Bilík
}

\begin{abstract}
Abstrakt: Na základě poznatků odborníků na oblast managementu, vedení škol a dalšího vzdělávání pedagogických pracovníků byl vytvořen model role ředitele školy v oblasti dalšího vzdělávání pedagogických pracovníků. Pro ověření některých dílčích aspektů vytvořeného modelu bude proveden kvantitativní výzkum. Pro tyto potřeby je vytvářen konkrétní dotazník. Hlavním cílem výzkumného projektu je poznat a popsat roli ředitele české základní školy v procesu dalšího vzdělávání pedagogických pracovníků a zjistit, co nejvíce ovlivňuje činnost ředitele školy v oblasti dalšího vzdělávání pedagogických pracovníků. Výsledky výzkumného projektu budou sloužit jako jedno z východisek pro stanovení dalšího postupu při dotváření koncepce dalšího vzdělávání pedagogických pracovníků v České republice.
\end{abstract}

Klíčová slova: model, ředitel školy, další vzdělávání pedagogických pracovníků, management, vedení škol, kvantitativní výzkum

\begin{abstract}
Based on the findings of experts for management field, school leadership and further education of teaching staff was created a model of headteacher's role in the process of further education of teaching staff. For verification some particular aspects of the model will be made a quantitative research. For these purposes is created a specific questionnaire. The main objective of this research is to identify and describe the role of the headmaster of Czech elementary school in the process of further education of teaching staff and find out what aspects most influence the activity of the headmaster in further education of teaching staff. The results of the research project will serve as one of the bases for determination of next steps in completing the concept of further education of teaching staff in the Czech Republic.
\end{abstract}

Keywords: model, headteacher/headmaster, further education of teaching staff, management, school leadership, quantitative research

\section{1 Úvodem}

Př́íspěvek navazuje na článek s názvem „Role ředitele základní školy v procesu dalšího vzdělávání pedagogických pracovníkủ“, který byl publikován ve Sborníku z mezinárodní vědecké konference ICOLLE 2010 (Bilík, 2010) a ve Sborníku prríspěvků XVIII. celostátní konference ČAPV (Bilík, 2011) a ve kterém autor na podkladě provedených analýz uvádí základní vhled do problematiky historie vývoje koncepce a realizace dalšího vzdělávání pedagogických pracovníků (DVPP) v českých zemích. 


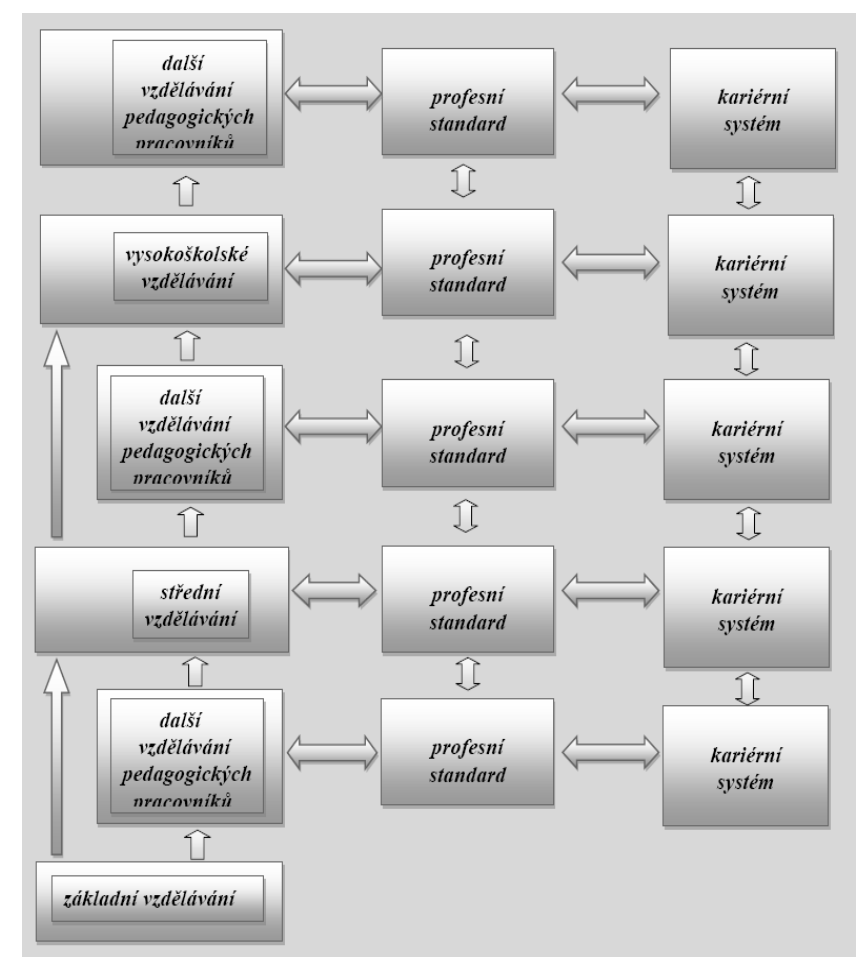

Obrázek 1. Vzdělávání pedagogických pracovníků.

Zdroj: autor.

Zmíněný autor představuje vlastní tezi, že existuje provázaný systém konceptů vzdělávání pedagogických pracovníků, dalšího vzdělávání pedagogických pracovníků, profesního standardu učitele (pedagogických pracovníků) a kariérního systému pedagogických pracovníků (viz obrázek 1), současně definuje a přibližuje čtenáři alespoň rámcově některé ze základních částí tohoto systému.

Dále se autor zabývá některými rolemi pedagogických pracovníků zapojených do procesu DVPP a v této souvislosti mimo jiné upozorňuje na skutečnost, že je nutno připustit, že podle $\S 2$ odst. 2 písm. f) zákona o pedagogických pracovnících ${ }^{1}$ je pedagogickým pracovníkem také asistent pedagoga, kterému k získání kvalifikace k výkonu povolání, kromě jiného, postačuje základní vzdělání a absolutorium programu DVPP zaměřeného na jeho přípravu². Tato skutečnost je zohledněna i ve schématu uvedeném na obrázku 1 . V dalších částech textu je pozornost autora soustředěna na osobu ředitele školy a jeho zákonnou povinnost vytvořit ve škole vhodné podmínky pro realizaci DVPP $^{3}$ a organizovat DVPP podle plánu dalšího vzdělávání, s ohledem ke studijním zájmům pedagogických pracovníků, potřebám a rozpočtu školy ${ }^{4}$.

\footnotetext{
${ }^{1}$ Zákon č. 563/2004 Sb., o pedagogických pracovnících a o změně některých zákonů (zákon o pedagogických pracovnících), ve znění pozdějších předpisů.

${ }^{2}$ § 20 písm. e) vyhlášky č. 317/2005 Sb., o dalším vzdělávání pedagogických pracovníků, akreditační komisi a kariérním systému pedagogických pracovníků, ve znění vyhlášky č. 412/2006 Sb.

${ }^{3} \S 164$ odst. 1 písm. e) zákona č. 561/2004 Sb., o předškolním, základním, středním, vyšším odborném a jiném vzdělávání (školský zákon), ve znění pozdějších předpisů.

${ }^{4} \S 24$ odst. 3 zákona o pedagogických pracovnících.
} 


\section{Cíl}

Cílem tohoto př́spěvku je navázat na již publikovaný text a dále pokračovat v započaté snaze obeznámit odbornou i laickou veřejnost $\mathrm{s}$ výzkumným projektem s názvem „Role ředitele základní školy v procesu dalšího vzdělávání pedagogických pracovníků “, který realizuje Ústav pedagogických věd Filozofické fakulty Masarykovy univerzity v Brně. Hlavními cíly tohoto projektu je poznat a popsat roli ředitele české základní školy v procesu DVPP, poznat a popsat rozpor mezi teoretickými požadavky kladenými na ředitele $\mathrm{v}$ dané oblasti a reálnou situací škol, jakož i zjistit, co ovlivňuje činnost ředitele školy v oblasti DVPP, získat a vyhodnotit náměty ředitelů škol na změnu jejich role v procesu DVPP a stanovit preference a klíčové kompetence ředitelů škol v oblasti DVPP.

\section{Materiál a metody}

Nejdř́ve se pokusme vysvětlit, co rozumíme pod pojmem role. Využijeme Pedagogický slovník (Průcha, Walterová \& Mareš, 2003), kde je definována sociální role jako chování, které skupina očekává od každého svého člena. Závisí na normách a hodnotách dané skupiny a na sociální pozici jedince ve skupině. Neplnění sociální role může pro jedince znamenat až vyloučení ze skupiny. Poznání sociálních rolí je důležité pro pochopení vztahů ve skupinách žáků i učitelů. Samotnou sociální pozici definuje zmíněný Pedagogický slovník jako postaveni jedince, které má v dané skupině. Jedná se o souhrn pravomocí, které skupina jedinci poskytuje na základě jeho chování a autority. Může být určena velmi obecně (např̀. ve vztahu k pohlaví) nebo může být více specifikována (např. sociální pozice určená zaměstnáním jedince)

Z těchto definic nám při zjednodušení vyplývá, že pokud hovoříme o roli ředitele školy, máme na mysli to, jak se ředitel školy chová a jak ze své pozice, dané mu školskou legislativou, jedná s pedagogickými pracovníky.

Víme tedy, co máme na mysli, když hovoříme o roli ředitele školy. Zbývá nám tedy ještě pokusit se vymezit tuto roli pro oblast DVPP. K tomu využijeme poznatků odborníků na oblast managementu, vedení škol a dalšího vzdělávání pedagogických pracovníků (Bacík, Svoboda \& Kalous et al., 1998; Eger et al., 1998, 2004; Lazarová et al., 2006; Máchal \& Horáčková, 2009; Solfronk, 2002; Stěpánek, 1993; Trojan, 2009) a vytvoříme základní model role ředitele školy v oblasti dalšiho vzdělávání pedagogických pracovníků (viz obrázek 2).

\subsection{Design výzkumného projektu}

Jako hlavní výzkumné metody tohoto projektu jsou zvoleny analýza dokumentů zaměřených na DVPP a dotazníkové šetření, při kterém bude osloven co největší počet ředitelů základních škol. Pro tyto potřeby je vytvořen konkrétní dotazník, který bude v rámci pilotáže otestován na malém vybraném vzorku respondentů tak, aby bylo možno ověřit jeho vhodnost pro stanovenou cílovou skupinu a současně ověřit využitelnost vytvořeného výzkumného nástroje vzhledem k tématu výzkumného projektu.

Na základě kvantitativního šetření se pokusíme odpovědět na otázky, zda a jak ovlivňuje roli ředitele školy v oblasti DVPP velikost školy a struktura školy, praxe ředitele školy, pohlaví ředitele školy a to, zda se jedná o školy venkovské či městské. 
Výzkumný projekt nám také pomůže při hledání odpovědi na otázku, zda ředitelé škol v oblasti řízení DVPP ve školách vystupují autoritativně, nebo zda zvolí spíše participační př́stup a také na otázku, jaké jsou jejich preference $\mathrm{v}$ oblasti DVPP. Jedním $\mathrm{z}$ výstupů projektu pak bude stanovení klíčových kompetencí ředitelů českých základních škol v oblasti DVPP.

\section{Výsledky a diskuze}

Na základě poznatků odborníků na oblast managementu, vedení škol a dalšího vzdělávání pedagogických pracovníků jsme vytvořili následující model role ředitele školy $\mathrm{v}$ oblasti dalšího vzdělávání pedagogických pracovníků.

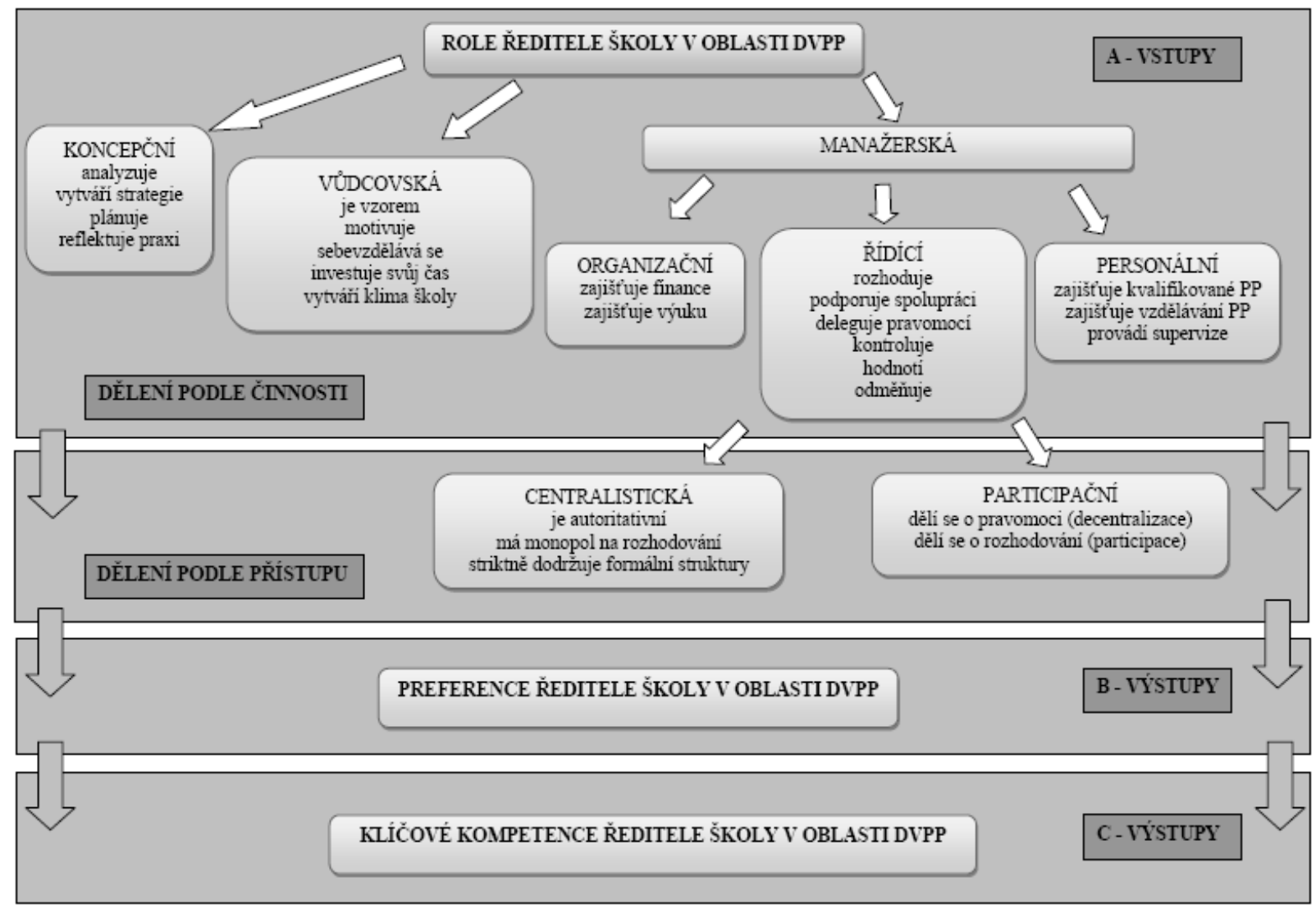

Obrázek 2. Role ředitele školy v oblasti DVPP. Zdroj: autor.

Pro hlubší pochopení uvedeného modelu je nutné, abychom si některé jeho vybrané aspekty více přiblížili.

\subsection{Koncepční role ředitele školy v oblasti DVPP}

Podle Solfronka (2002) znamená koncepční ř́zení systému určení smyslu a cílové funkce celého systému. 
Máchal a Horáčková (2009) definují strategické plánování jako určení dlouhodobých základních cílů organizace na základě rozboru vnějšího a vnitřního prostředí. Jedná se o vytvoření základní vize organizace do budoucnosti. Nejde však o určení nebo stanovení přesného způsobu vedoucího k dosažení cílů, nebot' podle autorů tuto funkci plní celá řada sekvenčních podpůrných plánů. Jak autoři také uvádějí, lze o strategickém plánování v souvislosti se školou hovořit coby o koncepci školy, a je nutné, aby tato obsahovala nejen poslání školy vycházející ze současné situace, ale i vize do budoucnosti. Vytvoření strategie je pro školu klíčovou záležitostí a vyžaduje spolupráci mezi vedením školy a jejími zaměstnanci.

Podle Egera (2004) musí ředitel školy v rámci plánování zabezpečit pracovní síly v náležité struktuře a kvalitě, dané školskými předpisy. Plán školy zaměřený na danou oblast musí zahrnovat přehled potřeb školy a vnitřních zdrojů a musí vycházet ze strategického plánu rozvoje školy. Plán rozvoje lidských zdrojů musí vycházet $\mathrm{z}$ analýzy současného stavu a analýzy vzdělávacích potřeb, jakož i korespondovat s cíli organizace. Musí také obsahovat časové členění, finanční aj. zabezpečení, odpovědnost a také vyhodnocení vzdělávání. Podle názoru autora bývají monitoring a evaluace výsledků DVPP slabou stránkou škol. V souvislosti se zabezpečením pracovních sil hovoří autor o plánování střednědobém (rok) a operativním (den).

\subsection{Vůdcovská role ředitele školy v oblasti DVPP}

Bacík, Svoboda a Kalous (1998) odkazují na definici autorů H. Koontze a H. Weihricha, která zní následovně: „Vůdcovství je definováno jako vliv, tj. jako umění nebo proces takového ovlivňování lidí, aby se snažili ochotně a nadšeně dosahovat skupinových cílü“. Autoři mimo jiné poukazují na problém výkladu termínu „leadership“, který je jedním $\mathrm{z}$ nejfrekventovanějších pojmů manažerské literatury a to nejen $\mathrm{v}$ anglicky mluvících zemích. Podle autorů je „leader“ („lídr") něco jiného než manažer. Manažer má za úkol vykonávat manažerské funkce, ale lídr je vůdce, který je zřetelně v čele, dokáže ostatní motivovat a vytvářet klima spolupráce. Autoři se tedy přiklánějí k překladu termínu „leadership“ slovem „vůdcovstvi““. Podle autorů nejde u leadershipu o pouhé organizování, ale o ovlivňování takovým způsobem, že lidé pracují horlivě, usilovně, s nadšením, přičemž jsou svým vůdcem stále inspirování. V tomto smyslu autorům nejvíce vyhovuje výše zmíněná Koontzeova a Weihricheova definice.

Na otázku motivace pracovníků klade důraz většina odborníků na oblast managementu a vedení škol. Máchal a Horáčková (2009) zdůrazňují, že manažerská práce by měla být zaměřena i na zjištování individuálních potřeb jednotlivců a tak povzbuzovat jednotlivé členy týmu v jejich seberealizaci. Formou pro povzbuzení individuální výkonnosti mohou být stimuly. Správně volené podněty mohou vytvářet prostředí, které bude příznivé pro určité snažení, mohou zvyšovat motivaci lidí. Stimuly jsou záležitosti, které ovlivňují chování jednotlivců a lidé se s jejich pomocí rozhodují, co a jak budou dělat.

Marc Van den Brande (2010), generální tajemník sdružení katolických základních škol Vlámského společenství v Belgii, na téže konferenci uvedl, s odkazem na provedené výzkumné šetření, že i ve Flanrech ředitelé škol řeší převážně neplánované úkoly a běžné problémy organizace a pouze $5 \%$ ze svého času mohou věnovat práci s podřízenými. 


\subsection{Organizační role ředitele školy v oblasti DVPP}

Solfronk (2002) v souvislosti s organizační rolí hovoří o důležitosti sestavování organizačních schémat školy, které podle jeho názoru mají dvojí smysl. Jednak vyjadřují strukturu řízení (rozdělení zodpovědností) a jednak určují dělbu práce (rozložení činností). Organizační schéma školy v nejjednodušší podobě má formu vazebně propojených kolonek, ve kterých je označena činnost (funkce) nebo konkrétní osoba. Podle autora velká škola chápe organizační schéma jako důležitou pomůcku pro zajištění chodu školy. Na malých školách se jeví organizační schéma jako méně důležité. Kvalitní organizační schéma školy zefektivňuje její řízení, usnadňuje řešení organizačních problémů a předchází mezilidským konfliktům. Je podkladem pro stanovení konkrétní náplně činnosti pedagogických i nepedagogických pracovníků školy.

Podle Egera (2004) musí ředitel školy v rámci plánování chodu školy dbát na zajištění potřebných financí. Zdůrazňuje, že ředitel školy zodpovídá za řádné využití finančních prostředků, které mu byly na DVPP přiděleny. Z materiálu Národního institutu pro další vzdělávání (NIDV, 2007) plyne, že financování DVVP se uskutečňuje v současnosti třemi způsoby. Jednak $\mathrm{z}$ peněz, které jsou vyčleněny $\mathrm{z}$ rozpočtu školy a jsou účelově vázány na DVVP. Výše těchto prostředků je dána počtem žákủ školy. Školy s nižším počtem žáků získávají tedy v rámci rozpočtu nižší finanční prostředky, které jsou určeny na DVPP. Tyto prostředky mohou být použity pouze na vzdělávací programy DVVP, které mají platnou akreditaci Ministerstva školství, mládeže a tělovýchovy (MŠMT), výjimečně na nákup studijní literatury pro pedagogické pracovníky. Druhou možností podpory DVPP jsou Rozvojové programy MŠMT, které jsou určeny k poskytování DVPP bezúplatně či za snížený účastnický poplatek nebo na hrazení nákladů spojených $\mathrm{s}$ DVPP. Jsou vyhlašovány pro oblasti vzdělávání, které jsou považovány za prioritní (např. vzdělávání v oblasti cizích jazyků. Třetí z možností jak financovat DVPP je využívat individuální projekty a globální projekty financované z Evropského sociálního fondu (ESF). Účelnost, věcnou a ekonomickou správnost využívání škole na DVPP účelově přidělených finančních prostředků kontroluje Česká školní inspekce (ČŠI).

\section{4 Řídici role ředitele školy v oblasti DVPP}

Kleskeň (2010), partner pražské pobočky společnosti McKinsey\&Company, na evropské konferenci ke kvalitnímu a efektivnímu vedení škol ve 21. století zdůraznil, že role ředitele školy je v řízení vzdělávání nenahraditelná. Joost den Oudsten (2010), z nizozemského ministerstva vzdělávání, kultury a vědy, na téže konferenci uvedl, že efektivnějšího a kvalitnějšího vedení škol není možné dosáhnout bez rozložení zodpovědností a úkolů, souvisejících s řízením škol. Je důležité podporovat rozvoj středního školského managementu a zapojit větší počet učitelů do řízení škol. Ředitelé škol nemusí znát a umět všechno, ale musí umět využít schopností a možností svých kolegů a přenést na ně část své práce. Lazarová (2006) odkazuje na Drago-Seversona, který za jeden ze základních pilírůo zaměřených na učení dospělých, považuje podporu spolupráce, tvorbu a řízení práce $\mathrm{v}$ týmu, tzv. teambuilding.

Štěpánek (1993) zdůrazňuje, že každý z vedoucích pracovníků by měl mít vytvořen určitý systém zjišt'ování výsledků, aby na základě toho byl kdykoliv schopen plnit svou usměrňující funkci. Teprve na základě objektivních informací je možné dobře řídit. Škola má sice své zákonitosti pohybu, svou rovnováhu, může nějak fungovat, jde však zejména o to, aby 
neztratila krok s vývojem, aby svým stylem práce nezaostávala za životem, za aktuálními potřebami.

Podle Egera (2004) je odměňování ve školství specifické, protože je do značné míry dáno jednak legislativou a dále nedostatkem finančních zdrojů. Je také skutečností, že v této oblasti existují velké rozdíly mezi jednotlivými školami. Autor odkazuje na Armstronga, podle kterého se systém odměňování skládá z peněžních odměn a zaměstnaneckých výhod, které v úhrnu tvoří celkovou odměnu. Systém také zahrnuje nepeněžní odměny (uznání, ocenění, úspěch, odpovědnost a osobní růst). Eger zdůrazňuje, že při plánování a realizování odměňování je dobré mít na paměti obecný cíl odměňování zaměstnanců, kterým je podpora dosažení strategických i krátkodobých cílů organizace tím, že odměňování pomáhá zabezpečit potřebné kvalifikované, oddané a motivované lidské zdroje. Plně to platí i pro školy. Podle autora by také mělo platit, že odměňování je vedeno $s$ tím záměrem, aby bylo jednoduché, srozumitelné a stimulující. Bacík, Svoboda a Kalous (1998) zdůrazňují, že př́liš nízká odměna vede $\mathrm{k}$ fluktuaci a naopak př́liš vysoká odměna může vést ke stagnaci. Mezi další nehmotné způsoby odměňování autoři řadí organizaci času, využití zařízení organizace, pracovní vybavení apod. Podle autorů je neúnosné, aby organizace nerozvíjela programy péče o zaměstnance. Management odměňování je považován za strategickou záležitost každé organizace.

\subsection{Personální role ředitele školy v oblasti DVPP}

Bacík, Svoboda a Kalous (1998) považují práci s lidmi za jednu z nejproblematičtějších oblastí manažerské činnosti. Upozorňují na různý př́stup autorů $\mathrm{k}$ této problematice a na problém s odlišnou terminologií. Nicméně zdůrazňují, že si nikdo z teoretiků managementu ani praktiků v oblasti řízení nemůže dovolit zaměření na činnost lidí jakkoli podcenit. Autoři odkazují na Weihrich - Koontzovu definici manažerské funkce v oblasti personalistiky, která o ní obecně hovoří, jako o obsazování pozic v organizační struktuře a udržování jejich obsazení.

Připomeňme, že základní nastavení systému DVPP v České republice je dáno vyhláškou o dalším vzdělávání pedagogických pracovníků a zákonem o pedagogických pracovnících, $\mathrm{v}$ rámci kterého si mohou pedagogičtí pracovníci zajistit splnění kvalifikačních předpokladů, splnění dalších kvalifikačních předpokladů a prohlubovat si svou odbornou kvalifikaci.

Lazarová (2006) odkazuje na Drago-Seversona, který považuje supervizi za součást základního pilíŕe vedení, zaměřeného na učení dospělých. Podle autorky patří mezi důležité odborníky v této oblasti také Bredeson a Johansson, kteří na základě rozhovorů s řediteli škol identifikovali konkrétní oblasti významného vlivu ředitelů na profesionální rozvoj učitelů, mezi které náleží také to, že ředitelé škol poskytují učitelům pravidelné supervize.

\section{Závěr}

Příspěvek navazuje na již publikované texty zaměřené na problematiku dalšího vzdělávání pedagogických pracovníků (Bilík, 2010), a dále pokračuje v započaté snaze obeznámit odbornou i laickou veřejnost s výzkumným projektem s názvem „Role ředitele základní školy v procesu dalšího vzdělávání pedagogických pracovníkư‘, který realizuje v rámci své vědecko-odborné činnosti na Ústavu pedagogických věd Filozofické fakulty Masarykovy univerzity v Brně.

Na základě analýzy prací odborníků zaměřených na oblast managementu, vedení škol a dalšího vzdělávání pedagogických pracovníků provedené v rámci teoretické části 
výzkumného projektu byl sestaven model role ředitele školy v oblasti DVPP (viz obrázek 2) a popsány jeho základní vstupní části a identifikovány výstupy ve formě preferencí a klíčových kompetencí ředitelů škol v oblasti DVPP.

Funkčnost představeného modelu bude za pomocí připravovaného kvantitativního šetření dále ověřována. Pro tyto potřeby je vytvořen speciální dotazník, který je připraven v rámci pilotáže k otestování na malém vybraném vzorku ředitelů českých základních škol tak, aby bylo možno ověřit jeho vhodnost pro stanovenou cílovou skupinu a současně ověřit využitelnost vytvořeného výzkumného nástroje vzhledem $\mathrm{k}$ tématu výzkumného projektu.

Potvrzuje se, že výzkumný záměr projektu „Role ředitele základní školy v procesu dalšího vzdělávání pedagogických pracovníkư“ je v souladu se závěry šetření, která byla provedena mezi vedoucími pracovníky odborů školství krajských úruadů (Trojan, 2009) a ze kterých vyplývá skutečnost, že role ředitele české školy je vymezena nedostatečně. Podle Trojana není žádná pracovní role či pozice izolovaným elementem, je nutno nejprve vymezit roli ředitele školy $\mathrm{v}$ širším kontextu, stanovit jeho klíčové oblasti a generovat jeho klíčové kompetence. Obdobně Kleskeň (2010), partner pražské pobočky společnosti McKinsey\&Company, na evropské konferenci ke kvalitnímu a efektivnímu vedení škol ve 21. století představil výsledky studie z roku 2007 potvrzující, že nejlepší vzdělávací systémy na světě jsou založené na kvalitním vedení lidí - leadershipu a že role ředitele školy je pro vzdělávání opravdu klíčová, nenahraditelná ve zlepšování kvality a řízení vzdělávání.

\section{Literatura}

Bacík, F., Kalous, J., \& Svoboda, J. (1998). Kapitoly ze školského managementu. Praha: Univerzita Karlova.

Bilík, J. (2010). Role ředitele základní školy v procesu dalšího vzdělávání pedagogických pracovníků. In D. Linhartová, P. Máchal \& L. Danielová (Eds.), Proceedings of international scientific conference ICOLLE 2010 (pp. 16-25). Brno: KONVOJ, spol. s r. o.. [CD-ROM]

Bilík, J. (2011). Role ředitele základní školy v procesu dalšího vzdělávání pedagogických pracovníků. In J. Wernerová (Ed.), Kam směřje současný pedagogický výzkum? Sborník př́spěvků XVIII. celostátni konference ČAPV. Liberec: Technická univerzita v Liberci. [CD-ROM]

Brande, M. V. (2010). Evropská konference ke kvalitnímu a efektivnímu vedení škol ve 21. století. Praha: MŠMT.

Eger, L. (1998). Efektivní školský management. Plzeň: Západočeská univerzita.

Eger, L. (2004). Personální řizení (se zaměřením na školství). Liberec: Technická univerzita v Liberci.

Kleskeň, B. (2010). Evropská konference ke kvalitnímu a efektivnimu vedení škol ve 21. století. Praha: MŠMT.

Lazarová, B. et al. (2006). Cesty dalšiho vzdělávání učitelů. Brno: Paido.

Máchal, P., \& Horáčková, M. (2009). Školský management. Brno: Mendelova zemědělská a lesnická univerzita.

NIDV (2007). Návrh řešení problematiky systému DVPP. Praha: NIDV.

Oudsten, J. (2010). Evropská konference ke kvalitnimu a efektivnímu vedení škol ve 21. století. Praha: MŠMT.

Průcha, J., Walterová, E., \& Mareš, J. (2003). Pedagogický slovník. Praha: Portál.

Solfronk, J. (2002). Kapitoly ze školského managementu. Liberec: Technická univerzita.

Štěpánek, F. (1993). Řizení školy: na pomoc řediteli̊m škol a učitelưm. Brno: Signet.

Štoček, M., \& Blažek, J. (1995). Ředitel školy jako manažer: úvahy nad problémy ředitele školy. Praha: Pražské centrum vzdělávání pedagogických pracovníků.

Trojan, V. (2009). Vzdělávání ředitelů škol a jejich kompetence. E-Pedagogium 1/2010. Dostupné z http://wiki.ceskaskola.cz/system/app/pages/search?q=e-Pedagogium_1-

2010_Trojan.pdf\&scope=search-site 


\section{Kontakt}

Mgr. Jan Bilík

Ministerstvo školství, mládeže a tělovýchovy (MŠMT)

Ústav pedagogických věd

Filozofická fakulta

Masarykova univerzita v Brně

A. Nováka 1, 60200 Brno

e-mail: jan.bilik@msmt.cz,15418@mail.muni.cz

\section{Bibliografické údaje}

Bilík, J. (2011). Model role ředitele školy v procesu dalšího vzdělávání pedagogických pracovníků. In T. Janík, P. Knecht, \& S. Šebestová (Eds.), Smišený design v pedagogickém výzkumu: Sborník př́spěvků z 19. výročni konference České asociace pedagogického výzkumu (s. 180-188). Brno: Masarykova univerzita.

Dostupné z: http://www.ped.muni.cz/capv2011/sbornikprispevku/bilik.pdf doi: 10.5817/PdF.P210-CAPV-2012-2 